\title{
Zonal Soil Amendment with Simple Sugars to Elevate Soil C/N Ratios as an Alternative Disease Management Strategy for Rhizoctonia Damping-off of Sugar Beet
}

Yukari Shimizu, Daiki Sagiya, Mariko Matsui, and Ryo Fukui, ${ }^{\dagger}$ Department of Agrobiology and Biosciences, Utsunomiya University, Utsunomiya, Tochigi, 321-8505, Japan

\begin{abstract}
Effects of monosaccharide-amended soils on suppression of Rhizoctonia damping-off of sugar beet were compared under controlled experiments. Suppressive effects of glucose, fructose, sorbose, and xylose were significantly $(P<0.001)$ greater than that of galactose or mannose but the effect of sorbose was reduced by soil treatments with antibiotics. Saprotrophic growth of Rhizoctonia solani in the laimosphere also was suppressed by glucose, fructose, sorbose, and xylose, whereas only sorbose repressed pericarp colonization. Sugar alcohols (mannitol, sorbitol, and xylitol) neither suppressed Rhizoctonia damping-off nor halted the saprotrophic growth of the pathogen. Seed germination was not affected by any of these six monosaccharides, whereas galactose and mannose inhibited

seedling emergence significantly $(P<0.001)$ compared with the nontreated control or other monosaccharides. Soil fertilization with inorganic nitrogen at a $\mathrm{C} / \mathrm{N}$ ratio of 20:1 negated the suppressive effects of glucose and fructose on both damping-off and saprotrophic colonization but improved seedling growth in carbonized soils. Obviously, microbial competition for mineral nitrogen was responsible for disease suppression; however, it delayed seedling growth after emergence. This paradox was resolved by adding glucose to the top $1-\mathrm{cm}$ surface-soil zone at a $\mathrm{C} / \mathrm{N}$ ratio of $50: 1$ or $125: 1$. This protected the laimosphere, resulting in effective disease suppression while complementarily enhancing seedling growth.
\end{abstract}

Soil amendment with organic matter improves fertility and physical qualities of a soil through the processes of soil flocculation and mineralization (Brady and Weil 2010). Such effects of organic matter are imperative for intensifying crop production not only in developing nations in the tropics and subtropical regions (Webster and Wilson 1980) but also in developed countries with their vast croplands suffering from soil erosion (Cook 2006).

Organic soil amendments are known to curb soilborne plant diseases through different mechanisms (Fukui 2003; Hoitink and Boehm 1999). These may include the establishment of suppressive microbial populations or communities (Garbeva et al. 2004; Hoitink and Boehm 1999; Mazzola 2004) or proliferation of specific antagonistic microorganisms in amended soils (Borneman and Becker 2007; Weller et al. 2002). Volatile antimicrobial isothiocyanates produced by residues of cruciferous crops or their seed meals containing glucosinolates is another mechanism (Motisi et al. 2009; Rosa and Rodrigues 1999).

Rhizoctonia solani Kühn, a fungal pathogen responsible for root rot and surface-soil zone damping-off diseases in many host plants, is known to cause significant economic losses in sugar beet production worldwide (Führer-Ithurrart et al. 2004). Several resistant lines of sugar beet have been identified against root or crown rot (Gaskill 1967; Hecker and Ruppel 1975, 1988; Panella et al. 1995). However, only a few resistant cultivars are available against damping-off in most crops, including sugar beets (Cook 2000, 2006; Nagendran et al. 2009). In conventional production systems, application of azoxystrobin was effective in controlling crown and root rot in sugar beet (Bolton et al. 2010; Kirk et al. 2008). However, repeated applications of the single-site fungicide could lead to the development of resistant strains (Djébali et al. 2014), signifying the need for organic options of disease control.

${ }^{\dagger}$ Corresponding author: R. Fukui; E-mail: ryo@cc.utsunomiya-u.ac.jp

Funding: H. Teduka, the owner and president of T\&T nursery, provided partial funding support for this study.

Accepted for publication 8 February 2018.

() 2018 The American Phytopathological Society
Many studies have shown that soil amendment with crop residues or other forms of organic materials suppressed Rhizoctonia dampingoff of sugar beet in Japan (Kasuya et al. 2006; Matsui et al. 2013; Watanabe et al. 2011). In some of these studies, residues of noncruciferous crops such as peanut (Arachis hypogaea L.) and taro (Colocasia esculenta L.) suppressed Rhizoctonia damping-off of sugar beet as effectively as those of Brassica rapa crops when incorporated into an infested soil (Matsui et al. 2013; Watanabe et al. 2011). In others, disease suppression was attributed to the proliferation of specific bacterial antagonists in the residue-amended soils (Kasuya et al. 2006). However, it was often noted that sugar beet seedlings were stunted in the soil with peanut residue, even though they did not show disease symptoms. Immobilization of inorganic nitrogen by a boosted proliferation of soil microbes was thought to be responsible for the delayed seedling growth in the soil with elevated $\mathrm{C} / \mathrm{N}$ ratios after residue amendment. Nevertheless, among the crop residues, only peanut residue consistently suppressed the disease in an acid soil below pH 5.0 (Watanabe et al. 2011) or at high soil temperatures above $27^{\circ} \mathrm{C}$ (Matsui et al. 2013). It was assumed that soluble carbohydrates with low molecular weights such as monosaccharides or organic acids exuded from peanut residue played a key role in disease suppression without amplifying antagonistic soil bacteria or enhancing seedling growth. Its suppressive effect on damping-off was negated only partially when the residue-amended soil was treated with the antibiotics (Kasuya et al. 2006).

The objectives of this study were to investigate soil amendments effects of various saccharides and sugar alcohol on (i) saprotrophic and parasitic activities of $R$. solani (AG2-2 IIIB) in the rhizosphere (RZS), spermosphere (SMS), or laimosphere (LMS) of sugar beet; (ii) production of maceration enzymes by the pathogen; and (iii) seedling emergence and subsequent growth in carbonated soils. Finally, various monosaccharides were evaluated for diseasesuppressive effects in soil fertilized with inorganic nitrogenous chemicals at different $\mathrm{C} / \mathrm{N}$ ratios. The goal was to develop a complementary method of soil application with monosaccharides that assures both disease control and vigorous seedling growth.

\section{Materials and Methods}

Soil, plant residue, carbohydrates, and fungal isolate used in the study. Upland soil ( $\mathrm{pH}$ approximately 5.1 to 5.6) of Haplic Andosols collected from a field plot located at the university farm 
(Mo'oka, Tochigi, Japan) was used throughout the study. The field plot has been fallowed for more than 15 years. The soil collected from the top 10-cm soil layer was homogenized by passing through a 2-mm (U.S. number 10) sieve (Kasuya et al. 2006) before being stored in a cool, shady place to maintain soil moisture. Prior to the tests, the water content of this soil was determined by the tension-plate assembly method at $-10 \mathrm{kPa}$ (Fukui et al. 1994a; Hillel 2004).

The dried ground residue of peanut (A. hypogaea 'Chiba- Handachi') was prepared following the method of Kasuya et al. (2006). The semipowdered flakes were stored in Ziploc food storage bags in desiccators at room temperature (RT) and used within a year after preparation.

In total, six monosaccharides and three sugar alcohols were tested in this study. The monosaccharides tested included D-(+)-glucose and D-(+)-galactose from Sigma-Aldrich (St. Louis); D-(-)-fructose, D-(+)-mannose, and D-(+)-xylose from Kanto Chemical Co. (Tokyo); and D-(-)-sorbose from MP Biomedicals (Solon, OH). The three sugar alcohols tested were D-(-)-mannitol (Kanto Chemical Co.), D-sorbose (Sigma-Aldrich), and xylitol (Tokyo Chemical Industry Co., Tokyo).

$R$. solani strain MAFF305222 (AG2-2 IIIB, from sugar beet) was obtained from the Gene Bank of the Ministry of Agricultural Sciences, Tsukuba, Ibaraki, Japan.

In vitro assay on mycelial growth with different carbohydrates. Strain MAFF305222 was grown in Sachs' broth medium (Luttrell 1958) amended with one of the six different monosaccharides (fructose, glucose, galactose, mannose, sorbose, and xylose) or one of the three sugar alcohols (mannitol, sorbitol, and xylitol) at $2.0 \%$ (wt/vol). A nonamended medium served as a control. The media $(20 \mathrm{ml})$ were contained in 90-mm-diameter Petri dishes, each inoculated with a 5-mm-diameter disk from the growing margins of $R$. solani on potato dextrose agar. The static cultures were prepared in triplicate and incubated at $24^{\circ} \mathrm{C}$. After 7 days, the mycelia were collected individually and rinsed with distilled sterile water. Weights were determined after air drying for 3 days in a ventilated oven at $50^{\circ} \mathrm{C}$.

Enzymatic assays. Extracellular activities of polygalacturonase (PG) secreted by strain MAFF305222 in the presence of each one of the aforementioned six monosaccharides and the three sugar alcohols used in the in vitro test were examined on pectin agarose (PA) medium (Cleveland and McCormick 1987). Likewise, the activity of endo- $\beta-1,4$-glucanase was assayed on carboxymethylcellulose agar (CMC) medium (Kasana et al. 2008). Both assays were done in duplicate for each monosaccharide or sugar alcohol. Enzymatic activities were evaluated visually by contrasting the clearance zones on the media with added sugars to those on the control plates without sugars. The experiment was repeated with three plates each of PA or CMC medium for each sugar and the control. The plates were incubated for approximately 1 to 3 days at $24^{\circ} \mathrm{C}$. Enzymatic reactions were verified every $24 \mathrm{~h}$ using one set of three plates for each time by observing the plates under a dissecting microscope at $\times 20$ magnification.

Effects of monosaccharides versus sugar alcohols on seed germination and seedling emergence. Vermiculite (medium particles, $10 \mathrm{~g}$ each) was placed in sterilized 90-mm-diameter glass Petri dishes and 25 seeds of sugar beet (Beta vulgaris L. 'Molino'; Hokkaido Sugar Co., Ltd. ['HMR95-07', Novartis International AG]) per plate were embedded onto the surface of vermiculite with their basal pore down, leaving the operculum of the seed visible for observation. Aqueous solutions of the aforementioned six monosaccharides and the three sugar alcohols were each prepared at $5.5 \mathrm{mM}$ with sterile distilled water and poured individually over the vermiculite at $25 \mathrm{ml} /$ dish. Nontreated seed were drenched with the same volume of sterile distilled water, and five replicates were prepared for each treatment. The dishes were covered with the lids to maintain moisture and incubated in a complete randomized design in the dark for 4 days at $24^{\circ} \mathrm{C}$.

For testing seedling emergence, nine sugar beet seeds were placed onto $15 \mathrm{~g}$ of the vermiculite filled in each cell ( 5 by $5 \mathrm{~cm}, 5 \mathrm{~cm}$ deep) of a 16-cell plastic seedling tray. After the seed were covered with $5 \mathrm{~g}$ of the vermiculite and watered with approximately $60 \mathrm{ml}$ of deionized water per cell, the trays were placed in the temperatureregulated $\left(27^{\circ} \mathrm{C}\right.$ daytime and $22^{\circ} \mathrm{C}$ nighttime) glasshouse unit $(22$ to $27^{\circ} \mathrm{C}$ glasshouse) to permit the seed to germinate. After incubation for 3 days, aqueous solutions of the six monosaccharides tested above were prepared at $5.5 \mathrm{mM}$ with deionized water and poured individually over the vermiculite at $40 \mathrm{ml} / \mathrm{cell}$. Nontreated seed were drenched with deionized water. Eighteen seeds in two adjacent cells were considered as a replicate, and the cell trays were arranged in randomized complete block (RCB) design with six replicates. All cells were watered with $40 \mathrm{ml}$ each of deionized water 6 and 9 days after sowing, and seedling emergence was verified 7 and 10 days after sowing. This test was done twice.

Effects of monosaccharides versus sugar alcohols on seedling emergence and survival in $\boldsymbol{R}$. solani-infested soil. The field soil was pasteurized by heating the soil in plastic containers placed in a water bath maintained at approximately 65 to $70^{\circ} \mathrm{C}$ for $30 \mathrm{~min}$ (Kasuya et al. 2006) to eliminate indigenous Pythium spp. (Morita and Tojo 2007). This pasteurized soil was infested with the inoculum of $R$. solani, prepared from the colonized barley grains by the method of Kasuya et al. (2006) at $0.1 \%$ (wt/wt), and $800 \mathrm{~g}$ of the infested soil was partitioned into eight plastic cups $(9 \mathrm{~cm}$ in diameter and $7 \mathrm{~cm}$ deep) for each treatment (fructose, glucose, galactose, mannose, sorbose, xylose, mannitol, sorbitol, and xylitol). A $200 \mathrm{mM}$ aqueous solution of each carbon compound was poured into the cups at $22 \mathrm{ml} /$ cup to adjust soil matric potential to $-10 \mathrm{kPa}$. Fifteen sugar beet seeds per cup were sown approximately $1 \mathrm{~cm}$ deep into the infested soil. The molecular mass of each aqueous carbon compound added into $100 \mathrm{~g}$ of the soil was equivalent to that of glucose added in the form of granules to the soil at $0.5 \%$ (wt/wt). Nontreated and noninfested soils moistened with distilled water were prepared for controls. A soil amended with the same molecular mass of citric acid monohydrate (Kanto Chemical Co.) was included to compare its effect on disease suppression with those by the monosaccharides. The cups were arranged in an RCB design, each replicated eight times, in the 22 to $27^{\circ} \mathrm{C}$ glasshouse and watered daily to maintain soil moisture at about $-10 \mathrm{kPa}$. The numbers of germinating and surviving seedlings as well as those killed by damping-off, visually monitored by the typical pinching-off symptoms, were counted 10 and 21 days after sowing.

An analogous test was performed to compare the effect of granular glucose mixed into the soil on disease suppression with the effects induced by six different granular disaccharides: cellobiose, maltose, trehalose, sucrose, $\alpha$-lactose, and $\beta$-lactose. Briefly, $600 \mathrm{~g}$ of the $R$. solani-infested pasteurized soil was mixed with $17.0 \mathrm{mmol}$ glucose (approximately $3.0 \mathrm{~g}$ or $0.5 \%$ [wt/wt]) or each of six disaccharides in the amount (approximately $8.0 \mathrm{mmol}$ ) with the same number of carbon atoms in $17.0 \mathrm{mmol}$ glucose. Soil moisture was adjusted to $-10 \mathrm{kPa}$ before sowing 15 seeds/cup. Nontreated and noninfested soils were included as controls. The experiment was arranged in an $\mathrm{RCB}$ design with six replicates in the 22 to $27^{\circ} \mathrm{C}$ glasshouse. The numbers of surviving seedlings were enumerated 10 and 21 days after sowing, as described.

In vivo assays on disease suppression in soils with monosaccharides plus antibiotics. The effects of three monosaccharides (glucose, sorbose, and xylose) on suppression of Rhizoctonia damping-off were examined in the infested soil treated with antibacterial antibiotics by the method described above. Briefly, the infested soil mixed with each monosaccharide at $28.0 \mathrm{mmol} \mathrm{kg}^{-1}$ (approximately $5.0 \%$ [wt $/ \mathrm{wt}$ ] for hexose and $4.2 \%$ for pentose) was partitioned into 12 cups, each with $100 \mathrm{~g}$ of the soil. A predetermined volume of an aqueous solution containing streptomycin sulfate (Sigma-Aldrich) and chloramphenicol (ICN Biochemicals, Aurora, $\mathrm{OH}$ ) was poured into 6 cups to adjust soil moisture and the concentrations of both antibiotics to $134 \mu \mathrm{g} / \mathrm{ml}$ of soil water at $-10 \mathrm{kPa}$. Likewise, the soil moisture in the other six cups was adjusted with distilled water. All cups were each seeded with 15 seeds and were arranged in an RCB design with six replicates in the 22 to $27^{\circ} \mathrm{C}$ glasshouse. The number of surviving seedlings was counted 10 and 21 days after sowing as described. This test was done twice.

In vivo assays on pericarp colonization in soils with monosaccharides or sugar alcohols. The effects of four different monosaccharides (glucose, sorbose, fructose, and xylose) and peanut residue on pericarp colonization by $R$. solani were examined to 
compare saprotrophic growth of the pathogen in the SMS of sugar beet with or without the antibiotics (Kasuya et al. 2006). The infested soil was mixed with each monosaccharide or dried peanut residue and moistened to $-10 \mathrm{kPa}$ with distilled water or an aqueous solution containing streptomycin sulfate and chloramphenicol (each at $129 \mu \mathrm{g} / \mathrm{ml}$ of soil water). Each cup was seeded with 15 seeds, covered with lids with ventilation holes, and incubated at $25^{\circ} \mathrm{C}$ in an RCB design with six replicates. After $48 \mathrm{~h}$, the pericarps were retrieved from the soils, rinsed with water, and plated on water agar (WA) containing streptomycin sulfate at $50 \mu \mathrm{g} \mathrm{ml}^{-1}$, with five pericarps per Petri dish. Pericarp colonization by $R$. solani was enumerated within 2 days at RT under a dissecting microscope based on the morphological characteristics of the hyphae growing out of the pericarps. An analogous test was performed with three hexoses (glucose, galactose, and mannose) and sugar alcohols (mannitol, sorbitol, and xylitol) using the infested soil without the antibiotics.

The amounts of mineral nitrogen and glucose exuded from sugar beet seed were approximated by immersing 50 seeds in triplicate in $10 \mathrm{ml}$ of distilled water maintained at $3^{\circ} \mathrm{C}$ for 3 days. The respective concentrations in the water were assessed semiquantitatively using Merckquant ammonium test strips, MQuant nitrate test strips (Merck KGaA, Darmstadt, Germany), and Quantofix glucose test strips (Macherey-Nagel, Düren, Germany).

In vivo assays on saprophytic activity of $R$. solani in sugar beet LMS and RZS. The saprotrophic activity of the pathogen in the LMS and RZS of sugar beet seedlings was examined in the soil amended with monosaccharides by modifying the method of Paulitz and Schroeder (2005) for quantifying Rhizoctonia spp. in soil. Briefly, the $R$. solani-infested soil was mixed individually with one of five different monosaccharides (glucose, galactose, sorbose, fructose, and xylose) at $28.0 \mathrm{mmol} \mathrm{kg}^{-1}$ or dried peanut residue at $0.5 \%(\mathrm{wt} / \mathrm{wt})$. Each treatment was partitioned into five cups, each containing $150 \mathrm{~g}$ of the soil. Upon adjusting the moisture to $-10 \mathrm{kPa}, 16$ autoclaved toothpicks made from untreated birch timber (Yanagi Products, Osaka, Japan) were inserted vertically into the soil. The cups, including those for nontreated and noninfested soils, were arranged in an RCB design with five replicates in the 22 to $27^{\circ} \mathrm{C}$ glasshouse and incubated for 7 days, with watering every day to maintain soil moisture near $-10 \mathrm{kPa}$. After 3 days of incubation, eight toothpicks marked at the soil line were removed from each cup and rinsed thoroughly with tap water. They were dissected individually using flamed heavy-duty scissors to remove a surface 5-mm section from the soil line and a bottom 5-mm section representing LMS and RZS, respectively. Two toothpick sections were plated individually onto two plates of WA containing chloramphenicol at $100 \mu \mathrm{g} \mathrm{ml}^{-1}$ and benomyl at $1.0 \mu \mathrm{g} \mathrm{ml}^{-1}$ (Paulitz and Schroeder 2005). Eight pairs of toothpick sections per replicate were arranged in two replica plates. The sections colonized by $R$. solani were enumerated within 2 days at RT under a dissecting microscope, as described. The remaining eight toothpicks in the soil were plated likewise after 7 days of incubation.

An analogous test was performed using glucose, galactose, mannose, and the previously mentioned three sugar alcohols.

Table 1. Effects of monosaccharides and sugar alcohols on mycelial growth of Rhizoctonia solani in a mineral broth medium and on germination of sugar beet seed in vermiculite

\begin{tabular}{|c|c|c|c|c|c|c|}
\hline \multirow[b]{3}{*}{ Sugars added $^{\mathrm{x}}$} & \multirow[b]{3}{*}{ Weight $(\mathbf{m g})^{\mathbf{y}}$} & \multirow[b]{3}{*}{ Germination $(\%)^{\mathrm{z}}$} & \multicolumn{4}{|c|}{$\begin{array}{l}\text { Number of seedlings emerged out of vermiculite without Rhizoctonia } \\
\qquad \text { solani }(n=18)^{\mathrm{w}}\end{array}$} \\
\hline & & & \multicolumn{2}{|c|}{ First trial } & \multicolumn{2}{|c|}{ Second trial } \\
\hline & & & After 7 days & After 10 days & After 7 days & After 10 days \\
\hline \multicolumn{7}{|l|}{ Mineral broth medium } \\
\hline Not added & $17.1 \mathrm{a}$ & 76.8 & $\ldots$ & $\ldots$ & $\ldots$ & $\ldots$ \\
\hline Glucose & $97.8 \mathrm{~d}$ & 83.2 & $\ldots$ & $\ldots$ & $\ldots$ & $\ldots$ \\
\hline Galactose & $61.1 \mathrm{bc}$ & 77.6 & $\ldots$ & $\ldots$ & $\ldots$ & $\ldots$ \\
\hline Mannose & $59.5 \mathrm{bc}$ & 86.4 & $\ldots$ & $\ldots$ & $\ldots$ & $\ldots$ \\
\hline Sorbose & $54.1 \mathrm{~b}$ & 76.8 & $\ldots$ & $\ldots$ & $\ldots$ & $\ldots$ \\
\hline Fructose & $80.1 \mathrm{c}$ & 83.2 & $\ldots$ & $\ldots$ & $\ldots$ & $\ldots$ \\
\hline Xylose & $61.5 \mathrm{bc}$ & 86.4 & $\ldots$ & $\ldots$ & $\ldots$ & $\ldots$ \\
\hline Mannitol & $55.8 \mathrm{bc}$ & 84.8 & $\cdots$ & $\cdots$ & $\cdots$ & $\cdots$ \\
\hline Sorbitol & $66.5 \mathrm{bc}$ & 81.6 & $\ldots$ & $\ldots$ & $\ldots$ & $\ldots$ \\
\hline Xylitol & $51.5 \mathrm{~b}$ & 76.8 & $\ldots$ & $\ldots$ & $\ldots$ & $\ldots$ \\
\hline \multicolumn{7}{|l|}{ Probability } \\
\hline Main effect & $<0.001$ & ns & $\ldots$ & $\ldots$ & $\ldots$ & $\ldots$ \\
\hline \multicolumn{7}{|l|}{ Medium or vermiculite } \\
\hline Not added & $\ldots$ & $\ldots$ & $13.0 \mathrm{~cd}$ & $14.3 d$ & $16.2 \mathrm{~d}$ & $16.5 \mathrm{~d}$ \\
\hline Glucose & $\ldots$ & $\ldots$ & $13.5 \mathrm{~d}$ & $14.3 \mathrm{~d}$ & $14.5 \mathrm{c}$ & $16.0 \mathrm{~cd}$ \\
\hline Galactose & $\cdots$ & $\begin{array}{l}\cdots \\
\cdots\end{array}$ & $5.7 \mathrm{~b}$ & $11.5 b$ & $10.7 \mathrm{~b}$ & $12.7 \mathrm{~b}$ \\
\hline Mannose & $\ldots$ & $\ldots$ & $0.5 \mathrm{a}$ & $0.7 \mathrm{a}$ & $2.7 \mathrm{a}$ & $0.5 a$ \\
\hline Sorbose & $\ldots$ & $\ldots$ & $14.2 \mathrm{e}$ & $15.3 e$ & $14.5 \mathrm{c}$ & $15.2 \mathrm{~cd}$ \\
\hline Fructose & $\ldots$ & $\ldots$ & $12.7 \mathrm{c}$ & $13.5 \mathrm{c}$ & $14.2 \mathrm{c}$ & $15.0 \mathrm{c}$ \\
\hline Xylose & $\cdots$ & $\cdots$ & $13.2 \mathrm{~d}$ & $14.5 d$ & $14.5 \mathrm{c}$ & $15.8 \mathrm{~cd}$ \\
\hline \multicolumn{7}{|l|}{ Probability } \\
\hline Main effect & $\ldots$ & $\ldots$ & $<0.001$ & & $<0.001$ & \\
\hline Repeated measure (days) & $\ldots$ & $\ldots$ & $<0.001$ & & 0.012 & \\
\hline Interaction & $\ldots$ & $\ldots$ & $<0.001$ & & $<0.001$ & \\
\hline
\end{tabular}

${ }^{w}$ Seed sown in vermiculite were drenched with a $5.5 \mathrm{mM}$ solution of each monosaccharide 3 days after sowing, and allowed to emerge in the 22 and $27^{\circ} \mathrm{C}$ glass house. Values are means of six replicates, 18 seeds/replicate (108 seeds in total). Two data sets are presented separately because the trial-repeated measure interaction and the effect of trial were significant acceding to analysis of variance. Means indicated by the same letters are not significantly different $(P=$ 0.05) within each assessment day according to the Student-Newman Keuls test. Means indicated by bold italic letters are significantly greater than the corresponding counterpart value assessed earlier, according to pairwise Tukey's test.

x Monosaccharides or sugar alcohols added.

y Dry mycelial weight $(\mathrm{mg})$ of $R$. solani $(n=3)$. Strain MAFF30522 of $R$. solani was grown in Sachs' broth medium containing $2.0 \%$ (wt/vol) of each monosaccharide or sugar alcohol for 7 days at $24^{\circ} \mathrm{C}$. Values are means of three replicates. Means with the same letters in each column are not significantly different $(P=0.05)$ according to the Student-Newman Keuls test.

${ }^{\mathrm{z}}$ Germination of sugar beet seed in vermiculite $(\%)(n=25)$. Seed were placed into vermiculite without the pathogen drenched with a 5.5 mM solution of each monosaccharide or sugar alcohol, and incubated in the dark for 4 days at $24^{\circ} \mathrm{C}$. Values are means of five replicates; ns $=$ not significant $(P>0.05)$. 
Effects of nitrogen fertilization on pathogenic and saprophytic activities of $\boldsymbol{R}$. solani. The effects of nitrogen fertilization on damping-off suppression were examined by uniformly moistening the infested soil with aqueous solutions containing glucose or fructose plus $\mathrm{KNO}_{3}$ or $\mathrm{NH}_{4} \mathrm{Cl}$. Upon sowing, $100 \mathrm{~g}$ of the soil was moistened with $16.0 \mathrm{ml}$ of distilled water or an aqueous solution of hexose at $170 \mathrm{mM}$ (approximately $0.5 \%$ [wt/wt]). For each treatment, the soils were moistened additionally with $8.0 \mathrm{ml}$ of $100 \mathrm{mM} \mathrm{KNO}_{3}$ or $\mathrm{NH}_{4} \mathrm{Cl}$ solution to adjust the $\mathrm{C} / \mathrm{N}$ ratio of the soil amendments to 20:1. The soils for controls were moistened with the same volume of distilled water or a solution of $100 \mathrm{mM} \mathrm{KCl}$. All soils were adjusted to $-10 \mathrm{kPa}$ soil moisture. Each cup was seeded with 15 sugar beet seeds. The trial was arranged in an RCB design with eight replicates in the 22 to $27^{\circ} \mathrm{C}$ glasshouse. The numbers of surviving seedlings were enumerated 10 and 21 days after sowing.

The effects of nitrogen fertilization on saprotrophic activities of $R$. solani were examined likewise in the soil with glucose or fructose. The infested soil was amended with $\mathrm{NH}_{4} \mathrm{NO}_{3}$ in the amount (4.2 mmol kg-1 or approximately $0.34 \%$ [wt/wt]) equivalent to a $\mathrm{C} / \mathrm{N}$ ratio of $20: 1$ in relation to the amount $\left(28.0 \mathrm{mmol} \mathrm{kg}^{-1}\right)$ of the hexose added to the soil. $\mathrm{NH}_{4} \mathrm{NO}_{3}$ was also added to the soil without hexoses, and their respective counterparts were prepared using the soil with no nitrogen. The soils with toothpicks were incubated in an RCB design with five replicates in the 22 to $27^{\circ} \mathrm{C}$ glasshouse. The numbers of colonization in the zones representing sugar beet LMS and RZS were determined after incubation for 3 and 7 days.

Effects of soil carbonization on growth enhancement in sugar beet seedlings. Growth of sugar beet seedlings was assessed in the pasteurized soil with or without saccharides to examine effects of soil amendment with nitrogen on restoration of seedling growth. The pasteurized soil was mixed with $28.0 \mathrm{mmol} \mathrm{kg}{ }^{-1}$ of glucose or fructose or $14.0 \mathrm{mmol} \mathrm{kg}^{-1}$ of sucrose (approximately $4.8 \%$ [wt/wt]). In addition, it was amended with $\mathrm{KNO}_{3}$ or $\mathrm{NH}_{4} \mathrm{Cl}$ at $8.13 \mathrm{mmol} \mathrm{kg}{ }^{-1}$ (approximately 0.044 and $0.084 \%$ [wt/wt], respectively) to adjust the $\mathrm{C} / \mathrm{N}$ ratio of the treatments to $20: 1$. The control soil was amended with no inorganic chemicals or with an equivalent molecular mass of $\mathrm{KCl}$ (approximately $0.63 \%$ [wt/wt]). The same treatments were made with the pasteurized soil without sugars. These soils (800 g each) were used to fill plastic garden pots $(12.5$ in diameter and $11 \mathrm{~cm}$ deep), with their drainage hole sealed to retain soil water. The pots were sown with 16 sugar beet seeds each, arranged in an RCB design with four replicates in the 22 to $27^{\circ} \mathrm{C}$ glasshouse, and watered daily to maintain soil moisture at about $-10 \mathrm{kPa}$. After about a week, the plants in each pot were thinned to 10 seedlings. In addition to these soils, four subsets of pots with the nonamended pasteurized soil were sown with the seed to monitor seedling growth progressively without the influence of carbon or nitrogen. The seedlings were removed 42 days after sowing, rinsed, and air dried in paper bags for 7 days at $80^{\circ} \mathrm{C}$ in a ventilated oven. Dry weights of the four nonamended subsets were determined 14, 21, 28, and 35 days after sowing, respectively.

A second trial was conducted to examine effects of soil amendment with nitrogen on seedling growth in the soils amended with four different monosaccharides that suppressed damping-off. Glucose, sorbose, and fructose were added to the soil at $28.0 \mathrm{mmol} \mathrm{kg}^{-1}$ and xylose was added at $33.5 \mathrm{mmol} \mathrm{kg}^{-1}$ (all approximately $0.5 \%$ [wt/wt]). Nitrogen was applied in the form of $\mathrm{NH}_{4} \mathrm{NO}_{3}$ at $4.2 \mathrm{mmol} \mathrm{kg}$ (approximately $0.034 \%$ [wt/wt]) to bring the $\mathrm{C} / \mathrm{N}$ ratio to $20: 1$. A third trial was performed with hexoses and sugar alcohols such as galactose, mannose, mannitol, sorbitol, and xylitol that did not suppress damping-off. $\mathrm{NH}_{4} \mathrm{NO}_{3}$ was applied likewise at a $\mathrm{C} / \mathrm{N}$ ratio of 20:1, and the soils with glucose and without carbon surfacesoil zone nitrogen were included in the test for comparison. The pots were arranged in an RCB design with four replicates in a regular

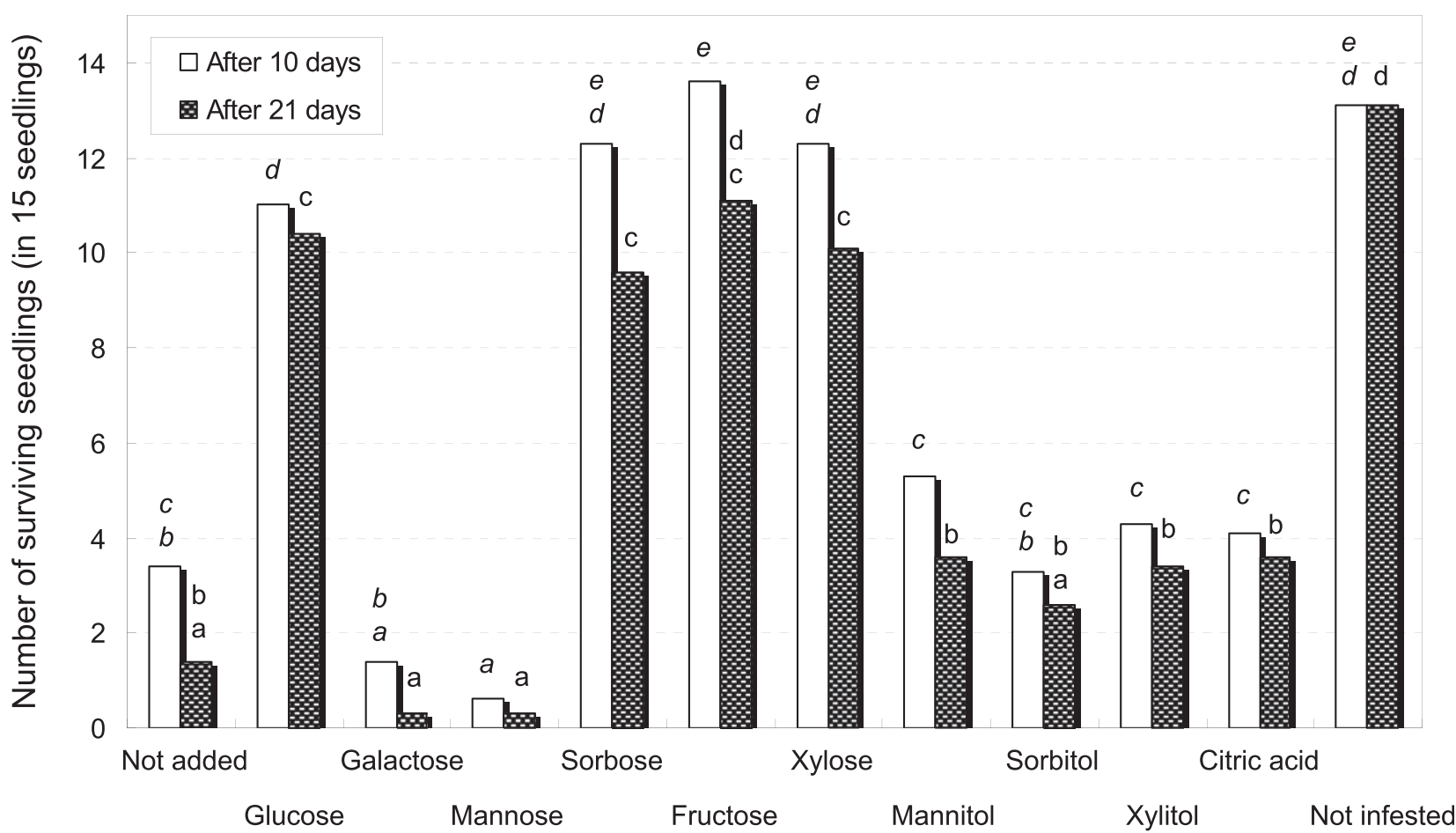

\section{Carbohydrates added to the soil}

Fig. 1. Effects of monosaccharides and sugar alcohols on seedling emergence and survival in the Rhizoctonia solani-infested pasteurized soil. Sugar beet seed were sown in the soil moistened with a $200 \mathrm{mM}$ solution of each carbon compound to adjust soil moisture to $-10 \mathrm{kPa}$. Values are means of eight replicates, 15 seeds/replicate. The main and repeated measure effects were both significant at $P<0.001$, with a significant interaction. Means indicated by the same letters are not significantly different $(P=0.05)$ within each assessment day according to the Student-Newman Keuls test. None of the means after 21 days were significantly different $(P=0.05)$ from the corresponding counterpart values assessed earlier according to pairwise Tukey's test. 
glasshouse, where indoor temperature near the pots was recorded every hour using an automated thermo-recorder (Espec Mic, Aichi, Japan). In both tests, dry weights of the whole seedlings were determined 42 days after sowing in late April, as described. When fewer than 10 seedlings grew per pot, average dry weight per seedling was multiplied by 10 .

Effects of glucose added to the surface versus the whole soil zone on disease suppression and seedling growth. For assessing disease incidence, $70 \mathrm{~g}$ of the infested soil amended with glucose and $\mathrm{NH}_{4} \mathrm{NO}_{3}$ at 28.0 and $4.2 \mathrm{mmol} \mathrm{kg}{ }^{-1}$ (C/N ratio at 20:1), respectively, was placed in the cup with a predetermined volume of distilled water to moisten $100 \mathrm{~g}$ of the soil to $-10 \mathrm{kPa}$. After 15 seeds were placed onto the soil, the same amended soil was overlaid approximately $1 \mathrm{~cm}$ deep to bring the soil weight to $100 \mathrm{~g} \mathrm{(505} \mathrm{mg} \mathrm{of} \mathrm{glucose}$ per cup). To add glucose only to the surface-soil zone at a $\mathrm{C} / \mathrm{N}$ ratio of 20:1, $70 \mathrm{~g}$ of the soil with $\mathrm{NH}_{4} \mathrm{NO}_{3}$ was placed first into the cup and overlaid with the same soil mixed with glucose at $28.0 \mathrm{mmol}$ $\mathrm{kg}^{-1}$ (151 mg of glucose per cup). The zonal applications with glucose at $\mathrm{C} / \mathrm{N}$ ratios of 50:1 and 125:1 (378 and $946 \mathrm{mg}$ of glucose per cup, respectively) were included in the test. The soils with nitrogen but no glucose (nontreated) and without the pathogen (noninfested) were prepared for the controls. The entire set of soil treatments was also made with the infested soil without nitrogen. The cups were arranged in an RCB design with six replicates in the regular glasshouse, and the numbers of surviving seedlings were enumerated 10 and 23 days after sowing in late February, as described. This test was repeated in the regular glasshouse from late April, with monitoring of the indoor temperature.

Effects of glucose added to the surface-soil zone on seedling growth were examined with the same set of treatments with $800 \mathrm{~g}$ of the pasteurized soil per pot by the methods described above. For surface applications, $240 \mathrm{~g}$ of the soil was mixed with glucose at a $\mathrm{C} / \mathrm{N}$ ratio of 20:1, 50:1, or 125:1 in relation to the amount of $\mathrm{NH}_{4} \mathrm{NO}_{3}$ amended into the soil at $4.2 \mathrm{mmol} \mathrm{kg}^{-1}$. This was used to cover $560 \mathrm{~g}$ of the soil with or without nitrogen after sowing 16 seeds/pot. The other treated soils were prepared likewise. After growing them with three replicates for 42 days from early March in the regular glasshouse, dry weights of 10 whole seedlings were determined.

Statistical analysis. Prior to data analysis, individual numbers of colonized pericarps or toothpick sections were subject to the multiple-infection transformation (Gregory 1948) to approximate the numbers of colonization by the pathogen $(N)$ using the equation $N=-n \ln (1-x / n)$, where $n$ refers to the number of samples per replicate and $x$ refers to colonized samples (Fukui et al. 1994b). When all samples were colonized, the value of $n-n^{-1}$ was used for the value of $x$.

Data were analyzed by analysis of variance to examine the main effect (carbohydrates) and those of associated factors (antimicrobials or inorganic nitrogen) using spreadsheets of Microsoft Excel 2010. Assessment day (days after sowing) and the position of toothpick sections were considered to be repeated measure factors in a twoway or three-way factorial arrangement. Means in multiple treatments were separated by the Student-Newman Keuls test $(P=$ $0.05)$. Tukey's procedure $(P=0.05)$ was used to compare pairs of means (repeated measurement) and to determine the treatments with the mean comparable with the nontreated or nonfertilized samples regardless of the number of means or their ranking in the data set.

\section{Results}

In vitro mycelial growth with monosaccharides or sugar alcohols. All monosaccharides and sugar alcohols added to the broth medium significantly $(P<0.001)$ enhanced the mycelial growth of $R$. solani isolate MAFF305522 as compared with that in the medium without them (Table 1). The growth was significantly the highest in the medium amended with glucose followed by fructose. The least mycelial growth among all carbohydrates was recorded with xylitol.

In vitro enzymatic activities by $R$. solani. There was no evidence to suggest suppression of enzymatic activities with carbohydrates. Distinct clearance zones became evident after staining all plates of PA medium with the fungal agar plugs. Clearance zones verified on the nontreated medium were comparable in their range as well as intensity with those on the medium with any of the monosaccharides or sugar alcohols. The same results were observed on CMC medium with the fungus after staining.

Extracellular enzymatic activities were also not amplified or suppressed when the fungus was grown with any polymers or monosaccharides before being transferred to the detection media. No clearance zones were observed around the inoculum plugs whether or not the WA used to grow the fungus contained pectin or CMC. In contrast, clearance zones became evident after colonization with

Table 2. Effects of monosaccharides added to soil on Rhizoctonia damping-off of sugar beet in the infested soil treated with antibiotics

\begin{tabular}{|c|c|c|c|c|}
\hline \multirow[b]{3}{*}{ Added to the soily } & \multicolumn{4}{|c|}{ Sugar beet seedlings survival in the infested soil $(n=6)^{x}$} \\
\hline & \multicolumn{2}{|c|}{ First trial } & \multicolumn{2}{|c|}{ Second trial } \\
\hline & After 10 days & After 21 days & After 10 days & After 21 days \\
\hline \multicolumn{5}{|l|}{ No antimicrobials added } \\
\hline Nontreated & $3.2 \mathrm{a}$ & $0.3 \mathrm{a}$ & $3.8 \mathrm{a}$ & $2.7 \mathrm{~b}$ \\
\hline Glucose & $9.7 \mathrm{~b}$ & $8.3 \mathrm{~b}$ & $13.0 \mathrm{e}$ & $13.0 \mathrm{~g}$ \\
\hline Sorbose & $12.5 \mathrm{~b}$ & $7.5 b$ & $11.8 \mathrm{~d}$ & $5.7 d$ \\
\hline Xylose & $10.8 \mathrm{~b}$ & $9.2 \mathrm{~b}$ & $11.5 \mathrm{c}$ & $10.0 \boldsymbol{e}$ \\
\hline \multicolumn{5}{|l|}{ Treated with antibiotics ${ }^{\mathrm{z}}$} \\
\hline Nontreated & $3.0 \mathrm{a}$ & $0.8 \mathrm{a}$ & $6.3 \mathrm{~b}$ & $4.0 c$ \\
\hline Glucose & $8.3 \mathrm{~b}$ & $6.8 \mathrm{~b}$ & $12.7 \mathrm{e}$ & $12.8 \mathrm{~g}$ \\
\hline Sorbose & $12.5 \mathrm{~b}$ & $0.3 a$ & $12.7 \mathrm{e}$ & $1.0 a$ \\
\hline Xylose & $8.8 \mathrm{~b}$ & $7.6 \mathrm{~b}$ & $11.2 \mathrm{c}$ & $10.5 f$ \\
\hline \multicolumn{5}{|l|}{ Probability } \\
\hline Monosaccharide (M) & $<0.001$ & & $<0.001$ & \\
\hline Antibiotics (A) & 0.004 & & ns & \\
\hline $\mathrm{M} \times \mathrm{A}$ interaction & ns & & $<0.001$ & \\
\hline Repeated measure & $<0.001$ & & 0.011 & \\
\hline
\end{tabular}

${ }^{x}$ Seedlings were grown in the pasteurized soil infested with Rhizoctonia solani at approximately 22 to $27^{\circ} \mathrm{C}$. Values are means of six replicates ( 90 seeds in total), 15 seeds/replicate. Means indicated by the same letters are not significantly different $(P=0.05)$ within each assessment day according to the Student-Newman Keuls test. Means indicated by bold italic letters are significantly different from the corresponding counterpart values assessed earlier according to pairwise Tukey's test $(P=0.05) ; \mathrm{ns}=$ not significant $(P>0.05)$.

${ }^{y}$ Antimicrobials and monosaccharides added to the soil. Seed were sown in the soil mixed with each monosaccharide at $28.0 \mathrm{mmol} \mathrm{kg}^{-1}$ soil (approximately $0.5 \%$ [wt/wt] with glucose) before adjusting soil moisture to $-10 \mathrm{kPa}$.

${ }^{\mathrm{z}}$ An aqueous solution containing predetermined amounts of streptomycin and chloramphenicol was added to the soils to adjust their concentration at $134 \mu \mathrm{g}$ each $\mathrm{ml}^{-1}$ to soil water at $-10 \mathrm{kPa}$. 
$R$. solani and progressively more extensive with longer incubation time. Nonetheless, the zones for these controls were not distinctively different in their range and intensity from those observed around $R$. solani with any of the monosaccharides or sugar alcohols.

Effects of carbohydrates on seed germination and seedling emergence. Seed germination was neither enhanced nor repressed when seed were incubated in vermiculite with aqueous solutions containing any monosaccharides or sugar alcohols tested (Table 1). Only galactose and mannose inhibited seedling emergence in vermiculite, with the latter being highly detrimental and even lethal to the seedlings.

However, glucose significantly improved seedling emergence and survival in the R. solani-infested soil (Fig. 1). Fructose, sorbose, and xylose also were effective in suppressing damping-off, with the mean for fructose after 21 days being comparable with that for noninfested soil. In contrast, galactose and mannose again hindered seedling emergence. Effects of citric acid and sugar alcohols on diseases suppression were limited compared with that of glucose.

All disaccharides (cellobiose, maltose, trehalose, sucrose, $\alpha$-lactose, and $\beta$-lactose) added to the infested soil in the second trial enhanced seedling survival to the numbers equivalent to that for glucose added into the infested soil or in pathogen-free soil. The numbers of surviving seedlings by 10 days after sowing ranged from 11.7 to 13.3 seedlings in the soils with any disaccharides, with no significant differences among them. These average numbers were significantly greater than 1.7 seedlings for nontreated, and equivalent to those for glucose (13.0) or noninfested (12.8). The number for nontreated decreased to 0.5 seedling by 21 days after sowing, whereas those for the disaccharides were 11.7 to 11.8 seedlings, which were comparable with 12.3 seedlings for glucose or 12.8 seedlings for noninfested.

Effects of antibiotics on disease suppression in the soils with monosaccharides. All four monosaccharides (fructose, glucose, sorbose, and xylose) enhanced seedling survival with no significant differences among their effects (Table 2). Soil treatment with streptomycin plus chloramphenicol had no effects on seedling survival by itself, and disease suppression induced by glucose or xylose was not affected in the soil with the antibiotics. However, the effect of sorbose on disease suppression was nullified by adding the antibiotics to the soil. Disease suppression induced by dried peanut residue was less effective than the effect by glucose or fructose or xylose by 21 days after sowing in the soil with the antibiotics.

In a second trial, both glucose and xylose added to the soil with or without antibiotics markedly suppressed the disease, and the antibiotics themselves had no effects on disease occurrence or suppression. In contrast, sorbose added to the soil without antibiotics provided a limited effect on disease suppression, which was nullified by treating the soil with the antibiotics (Table 2).

Effects of carbohydrates on pericarp colonization by $R$. solani. Soil treatment with the antibiotics had no effects on pericarp colonization by the pathogen or on the effects of carbohydrates (Table 3). Glucose, fructose, or xylose did not exhibit suppressive effects on pericarp colonization whether or not the soil was treated with the antibiotics. However, the number for pericarp colonization for glucose or fructose as well as the nontreated slightly increased with the antibiotics, whereas the opposite was observed for xylose. In contrast, sorbose and peanut residue repressed pericarp colonization, resulting in significantly lower values than the nontreated only in the soil with the antibiotics. None of the hexoses or sugar alcohols tested in the second trial affected the pathogen colonizing the pericarp.

The test strips revealed that one seed of sugar beet exuded approximately $2 \mu \mathrm{g}$ of $\mathrm{NH}_{4}^{+}$and $5 \mu \mathrm{g}$ of $\mathrm{NO}_{3}^{-}$and no more than $10 \mu \mathrm{g}$ of glucose in 3 days.

Effects of carbohydrates on saprotrophic growth of $R$. solani in the LMS versus RZS. During the first 3 days of incubation, none of the monosaccharides (fructose, galactose, glucose, sorbose, or xylose) or peanut residue had significant effects on colonization of toothpick sections by the pathogen in both soil zones (Table 4). However, colonization frequency increased within the next 4 days in the soil with added galactose, sorbose, or peanut residue. $R$. solani colonization with galactose was comparable with that in nontreated or residue-amended LMS after 7 days of incubation. In contrast, colonization frequency was repressed in soil with added glucose, fructose, or xylose even after 7 days of incubation. The overall trend in the zone of RZS was similar to that in the LMS, except the effect of galactose was comparable with those of other monosaccharides.

Mannose tested in the second trial also was as effective as glucose in suppressing colonization in both soil zones, whereas three sugar alcohols had no or limited effects in reducing colonization frequency in either soil zone (Table 4).

Effects of glucose and fructose added with inorganic nitrogen to the soils on pathogenic versus saprotrophic activities of $\boldsymbol{R}$. solani. Glucose or fructose added to the infested soil with no nitrogen suppressed damping-off effectively, whereas soil amendment with $\mathrm{NH}_{4} \mathrm{Cl}$ or $\mathrm{KNO}_{3}$ had no effects on disease suppression (Fig. 2A). However, such disease suppressions by glucose and fructose were nullified by adding $\mathrm{KNO}_{3}$ to the soil at a C/N ratio of 20:1. The equivalent neutralizing effect was observed for $\mathrm{NH}_{4} \mathrm{Cl}$, with its effect being slightly less than that of $\mathrm{KNO}_{3}$. Adding $\mathrm{KCl}$ to the soil had no effects on disease occurrence by itself or on disease suppression induced by the monosaccharides.

Soil amendment with $\mathrm{NH}_{4} \mathrm{NO}_{3}$ itself had no effects on colonization of toothpick sections by the pathogen but significantly reduced the effects of glucose and fructose on reducing colonization frequency in both soil zones with the same $\mathrm{C} / \mathrm{N}$ ratio (Fig. 2B).

Seedling growth in carbonated soils fertilized with inorganic nitrogen. Glucose, fructose, and sucrose all impeded the growth of sugar beet seedlings when applied to the pasteurized soil without nitrogen. However, when such carbonized soils were fertilized with $\mathrm{KNO}_{3}$ at a C/N ratio of 20:1, seedling growth was markedly improved to achieve dry matter weights (approximately 1.40 to

Table 3. Effects of monosaccharides and sugar alcohols added to the Rhizoctonia solani-infested pasteurized soil on colonization of sugar beet pericarp by the pathogen ${ }^{v}$

\begin{tabular}{lccc}
\hline & \multicolumn{3}{c}{$\begin{array}{c}\text { Numbers of pericarp colonization by } \boldsymbol{R} \text {. solani } \\
(\boldsymbol{n}=\mathbf{6})^{\mathbf{w}}\end{array}$} \\
\cline { 2 - 4 } & \multicolumn{3}{c}{ First trial } \\
\cline { 2 - 4 } Added to the soil $^{\mathbf{x}}$ & No antibiotics & With antibiotics $^{\mathbf{y}}$ & Second trial \\
\hline Nontreated & $27.2 \mathrm{ab}$ & $37.6 \mathrm{~b}$ & $63.8 \mathrm{~B}$ \\
Glucose & $26.4 \mathrm{ab}$ & $33.1 \mathrm{~b}$ & $47.0 \mathrm{~B}$ \\
Fructose & $27.8 \mathrm{ab}$ & $42.5 \mathrm{~b}$ & - \\
Sorbose & $5.7 \mathrm{a}$ & $3.4 \mathrm{a}$ & - \\
Xylose & $42.1 \mathrm{~b}$ & $23.7 \mathrm{ab}$ & - \\
Dried peanut residue & $4.6 \mathrm{a}$ & $7.4 \mathrm{a}$ & - \\
Galactose & - & - & $57.8 \mathrm{~B}$ \\
Mannose & - & - & $50.5 \mathrm{~B}$ \\
Mannitol & - & - & $60.6 \mathrm{~B}$ \\
Sorbitol & - & - & $55.4 \mathrm{~B}$ \\
Xylitol & - & - & $64.5 \mathrm{~B}$ \\
Not infested & - & - & $0.0 \mathrm{~A}$ \\
Probability & & & $\ldots$ \\
Main effect (M) & $<0.001$ & & $\ldots$ \\
Antibiotics (A) & $\mathrm{ns}$ & & \\
M $\times$ A interaction & $\mathrm{ns}$ & & \\
\hline
\end{tabular}

v Sugar beet seed were incubated for $48 \mathrm{~h}$ at $25^{\circ} \mathrm{C}$ in the pasteurized soil infested with the inoculum of $R$. solani at $0.1 \%$ (wt/wt).

${ }^{w}$ Number of pericarps colonized by the pathogen in each replicate was transformed by the multiple-infection transformation. Values (per 15 seeds) are means of six replicates. Means indicated by the same letters are not significantly different $(P=0.05)$ in each trial according to the Student-Newman Keuls test; - indicates not tested in the trial and ns $=$ not significant $(P>$ $0.05)$.

${ }^{x}$ Each monosaccharide or sugar alcohol was added to the soil at $27.5 \mathrm{mmol}$ $\mathrm{kg}^{-1}$ soil (equivalent to $0.5 \%$ [wt/wt] with glucose) before adjusting soil $\Psi_{\mathrm{m}}$ to $-10 \mathrm{kPa}$.

y Streptomycin and chloramphenicol were added to the soil in an aqueous solution for adjusting soil $\Psi_{\mathrm{m}}$ to achieve the concentration of each antibiotic in the soil water at $129 \mu \mathrm{g} \mathrm{ml}^{-1}$.

${ }^{\mathrm{z}}$ Dried peanut residue was added to the soil at $0.5 \%(\mathrm{wt} / \mathrm{wt}$ ) before adjusting soil $\Psi_{\mathrm{m}}$ to $-10 \mathrm{kPa}$. 
$1.47 \mathrm{~g}$ ) comparable with that in the plain soil with no sugars and nitrogen added (Fig. 3A). Average dry weights ( \pm one standard deviation) of 10 subset seedlings grown for 14, 21, 28, and 35 days in the nontreated pasteurized soil were $161 \pm 12,381 \pm 37,708 \pm 82$, and $1247 \pm 74 \mathrm{mg}$, respectively. $\mathrm{NH}_{4} \mathrm{Cl}$ added to the carbonized soils also enhanced seedling growth, and the dry matter weights (approximately 1.21 to $1.34 \mathrm{~g}$ ) determined after 42 days in such soils were comparable with the weight of the subsets grown for 35 days in the nontreated soil. $\mathrm{KCl}$ was more effective than either nitrogenous compound in enhancing seedling growth in the soil with no sugars but did not improve growth of the seedlings severely repressed in any carbonized soils.

All monosaccharides and sugar alcohols tested in the second and third trials suppressed the growth of the seedling when added without nitrogen (Fig. 3B and C). In addition, many seedlings died after emergence in the pasteurized soil containing sorbose and xylose in the second trial, resulting in only 4.0 and 5.8 seedlings, respectively, surviving 42 days after sowing. No seedlings emerged in the soil with galactose or mannose in the third trial. However, when these soils were fertilized with $\mathrm{NH}_{4} \mathrm{NO}_{3}$ at a $\mathrm{C} / \mathrm{N}$ ratio of $20: 1$, both seedling growth and survival were improved markedly in all cases (Fig. 3C). With inorganic nitrogen, all 10 seedlings emerged and grew in the soil with sorbose and xylose. With galactose and mannose amendment, 9.8 and 4.3 seedlings, respectively, emerged and grew in the soils. In both tests, seedling growth improved with glucose and $\mathrm{NH}_{4} \mathrm{NO}_{3}$ to yield dry matters comparable with those in the nontreated plain soil.

Effects of glucose added to the surface- versus whole-soil zone on disease suppression and seedling growth. Glucose added to the soil with no nitrogen effectively contained damping-off for 21 days whether it was mixed into the whole soil or only applied to the surface-soil zone at any rates (Table 5). In contrast, in the soil fertilized with $\mathrm{NH}_{4} \mathrm{NO}_{3}$ and amended with glucose to either zone at a $\mathrm{C} / \mathrm{N}$ ratio of 20:1, damping-off developed beyond 10 days. However, glucose added to the surface-soil zone at a $\mathrm{C} / \mathrm{N}$ ratio of $50: 1$ or 125:1 was more effective in suppressing the disease than glucose applied to either soil zone at a $\mathrm{C} / \mathrm{N}$ ratio of 20:1. The same effects of glucose were observed in the second trial, with glucose added to the surface zone at a $\mathrm{C} / \mathrm{N}$ ratio of 50:1 or above being significantly effective in suppressing the disease on both assessment days.

In the soil with no nitrogen, seedling growth was less repressed by adding glucose to the surface-soil zone at any $\mathrm{C} / \mathrm{N}$ ratio than adding it to the whole soil (Table 5). Soil fertilization with $\mathrm{NH}_{4} \mathrm{NO}_{3}$ enhanced seedling growth in all cases, with the dry matter weight for glucose added to the surface zone at a $\mathrm{C} / \mathrm{N}$ ratio of 50:1 being comparable with the seedling weight in the soil with nitrogen but no glucose.

\section{Discussion}

Among the sugars tested, glucose, fructose, and xylose were the most effective soil amendments that consistently suppressed

Table 4. Effects of monosaccharides versus dried peanut residue added to the infested soil on colonization of toothpick sections by Rhizoctonia solani ${ }^{\mathrm{w}}$

\begin{tabular}{|c|c|c|c|c|c|c|}
\hline \multirow[b]{3}{*}{ Added to the soily } & \multicolumn{4}{|c|}{$\begin{array}{l}\text { Numbers of colonization of toothpick sections by } R \text {. solani } \\
\qquad(n=5)^{\mathrm{x}}\end{array}$} & & \\
\hline & \multicolumn{2}{|c|}{ After 3 days } & \multicolumn{2}{|c|}{ After 7 days } & \multicolumn{2}{|c|}{ Probabilities } \\
\hline & LMS & RZS & LMS & RZS & First trial & Second trial \\
\hline \multicolumn{7}{|l|}{ First trial } \\
\hline Nontreated & $10.1 \mathrm{a}$ & $10.7 \mathrm{a}$ & $20.4 \mathrm{~b}$ & $12.5 \mathrm{~b}$ & $\ldots$ & $\ldots$ \\
\hline Glucose & $7.6 \mathrm{a}$ & $4.5 \mathrm{a}$ & $4.4 \mathrm{a}$ & $1.6 \mathrm{ab}$ & $\ldots$ & $\ldots$ \\
\hline Galactose & $7.2 \mathrm{a}$ & $8.0 \mathrm{a}$ & $21.5 \mathrm{~b}$ & $9.3 \mathrm{ab}$ & $\ldots$ & $\ldots$ \\
\hline Sorbose & $1.8 \mathrm{a}$ & $2.5 \mathrm{a}$ & $9.6 \mathrm{a}$ & $5.6 \mathrm{ab}$ & $\ldots$ & $\ldots$ \\
\hline Fructose & $5.8 \mathrm{a}$ & $2.8 \mathrm{a}$ & $3.9 \mathrm{a}$ & $4.3 \mathrm{ab}$ & $\ldots$ & $\ldots$ \\
\hline Xylose & $4.9 \mathrm{a}$ & $4.6 \mathrm{a}$ & $7.4 \mathrm{a}$ & $3.9 \mathrm{ab}$ & $\ldots$ & $\ldots$ \\
\hline Dried peanut residue $\mathrm{z}$ & $1.2 \mathrm{a}$ & $1.3 \mathrm{a}$ & $26.6 b$ & $25.5 c$ & $\ldots$ & $\ldots$ \\
\hline Not infested & $0.0 \mathrm{a}$ & $0.0 \mathrm{a}$ & $0.0 \mathrm{a}$ & $0.0 \mathrm{a}$ & $\ldots$ & $\ldots$ \\
\hline \multicolumn{7}{|l|}{ Second trial } \\
\hline Nontreated & $13.8 \mathrm{~b}$ & $4.6 \mathrm{a}$ & $33.3 c$ & $29.9 d$ & $\ldots$ & $\ldots$ \\
\hline Glucose & $4.8 \mathrm{a}$ & $2.3 \mathrm{a}$ & $5.0 \mathrm{a}$ & $2.5 \mathrm{a}$ & $\ldots$ & $\ldots$ \\
\hline Galactose & $4.5 \mathrm{a}$ & $2.9 \mathrm{a}$ & $16.0 \mathrm{~b}$ & $9.6 \mathrm{~b}$ & $\ldots$ & $\ldots$ \\
\hline Mannose & $4.9 \mathrm{a}$ & $3.8 \mathrm{a}$ & $3.2 \mathrm{ab}$ & $3.3 \mathrm{ab}$ & $\ldots$ & $\ldots$ \\
\hline Mannitol & $7.1 \mathrm{a}$ & $3.1 \mathrm{a}$ & $33.3 c$ & $21.1 c$ & $\ldots$ & $\ldots$ \\
\hline Sorbitol & $7.5 \mathrm{a}$ & $10.2 \mathrm{a}$ & $33.3 c$ & $33.3 d$ & $\ldots$ & $\ldots$ \\
\hline Xylitol & $12.6 \mathrm{~b}$ & $5.5 \mathrm{a}$ & $33.3 c$ & $21.1 c$ & $\ldots$ & $\ldots$ \\
\hline Not infested & $0.0 \mathrm{a}$ & $0.0 \mathrm{a}$ & $0.0 \mathrm{a}$ & $0.0 \mathrm{a}$ & $\ldots$ & $\ldots$ \\
\hline \multicolumn{7}{|l|}{ Probabilities } \\
\hline Main effect (M) & $\ldots$ & $\ldots$ & $\ldots$ & $\ldots$ & $<0.001$ & $<0.001$ \\
\hline \multicolumn{7}{|l|}{ Repeated measures } \\
\hline Days after insertion (D) & $\ldots$ & $\ldots$ & $\ldots$ & $\ldots$ & $<0.001$ & $<0.001$ \\
\hline Soil position (SP) & $\ldots$ & $\ldots$ & $\ldots$ & $\ldots$ & 0.042 & $<0.001$ \\
\hline $\mathrm{M} \times \mathrm{D}$ interaction & $\ldots$ & $\ldots$ & $\ldots$ & $\ldots$ & $<0.001$ & $<0.001$ \\
\hline $\mathrm{M} \times \mathrm{SP}$ interaction & $\ldots$ & $\ldots$ & $\ldots$ & $\ldots$ & ns & ns \\
\hline $\mathrm{D} \times \mathrm{SP}$ interaction & $\ldots$ & $\ldots$ & $\ldots$ & $\ldots$ & ns & ns \\
\hline Three-way interaction & $\ldots$ & $\ldots$ & $\ldots$ & $\ldots$ & $\mathrm{ns}$ & $\mathrm{ns}$ \\
\hline
\end{tabular}

${ }^{\mathrm{w}}$ In total, 16 toothpicks per replicate were inserted vertically into the pasteurized soil infested with the inoculum of $R$. solani at $0.1 \%$ (wt/wt) and incubated for 7 days at 22 and $27^{\circ} \mathrm{C}$ in the glasshouse; 8 of 16 toothpicks were sampled on each assessment day. Means indicated by the same letters are not significantly different $(P=0.05)$ within each column according to the Student-Newman Keuls test. Means indicated by bold italic letters are significantly different $(P=0.05)$ from the corresponding counterpart values assessed earlier according to pairwise Tukey's test; ns $=$ not significant $(P>0.05)$.

${ }^{x}$ Number of toothpick sections colonized by the pathogen in each replicate was transformed by the multiple-infection transformation. Values (per eight sections) are means of five replicates. Pairs of means (laimosphere [LMS] versus rhizosphere [RZS]) indicated by italic numbers are significantly different $(P=0.05)$ from each other according to pairwise Tukey's test. LMS: 5-mm sections of the toothpicks positioned from the soil surface and below. RZS: 5-mm sections of the toothpicks positioned from the bottom of the soil and above.

${ }^{y}$ Each monosaccharide or sugar alcohol was added to the soil at $28.0 \mathrm{mmol} \mathrm{kg}^{-1}$ soil (approximately $0.5 \%$ [wt/wt] with glucose) before adjusting soil moisture to $-10 \mathrm{kPa}$.

${ }^{\mathrm{z}}$ Dried peanut residue was added to the soil at $0.5 \% \mathrm{wt} / \mathrm{wt}$ before adjusting soil moisture to $-10 \mathrm{kPa}$. 
Rhizoctonia damping-off. However, xylose may not be recommended for practical use because it could reduce seedling emergence in the pasteurized soil without nitrogen. The mode of disease suppression by these monosaccharides clearly differed from that induced by soil amendment with dried crop residues (Kasuya et al. 2006; Matsui et al. 2013), because soil treatment with two antibacterial antibiotics did not interfere with disease suppression in the carbonized soils. The results suggest that microbial competition for mineral nitrogen was responsible for suppression of damping-off. Saprotrophic as well as pathogenic activities of the pathogen contained in carbonized soils were restored by fertilizing the soils with inorganic nitrogen.

The direct effects of carbohydrates on $R$. solani and the seedlings differed from their effects on depleting soil mineral nitrogen for the pathogen versus the host plant, depending on their molecular structure. Whereas all saccharides and sugar alcohols served as carbon sources for the pathogen, in vitro mycelial growth was significantly greater with glucose than any other carbohydrate. None of the carbohydrates impeded seed germination but seedling emergence was inhibited by galactose and mannose. When applied to the seeding bed of vermiculite, the latter virtually killed the seedlings, likely through its phytotoxicity (Pego et al. 1999). This is obviously the reason for the poor seedling emergence in the infested soil. Although all carbohydrates tested severely hindered the growth of the seedlings in the pasteurized soil, the three sugar alcohols neither interfered with the saprotrophic activity of the pathogen nor effectively suppressed the disease. These results indicate that the differential effects of carbohydrates on the pathogen versus the host plant are the key to using such monosaccharides, and perhaps more complex organic materials, for disease control.

Among the factors associated with exogenous supplies of saccharides, activities of macerating enzymes produced by the pathogen are considered to play major roles in the infection process and its virulence. $R$. solani, a necrotrophic parasite, degrades cell walls by secreting PG acting specifically on middle lamella of the host tissues and kills root cells before its hyphae invade the root (Isaac 1991). Weinhold and Bowman (1974) reported that the addition of exogenous glucose into soil resulted in reduced virulence of $R$. solani on young cotton (Gossypium hirsutum L.) seedlings, although it did not inhibit the formation of the infection cushion on the hypocotyl. They noted that there were direct relationships between utilization of monosaccharides by the pathogen as a carbon source, reduced virulence, and repression of pectinases. The cause of disease suppression was attributed to reduced activity of pectinolytic enzymes secreted by the pathogen, because in vitro enzyme production by the pathogen was prevented in a solution containing $28 \mathrm{mM}$ glucose. It was also shown that cellulases produced by the cellulolytic fungi such as Trichoderma reesei were inhibited by the presence of glucose or cellobiose, the product of enzymatic cellulose hydrolysis, in reactors (Andrić et al. 2010).

The results of our study demonstrate, however, that reduced secretions or activities of macerating enzymes by the pathogen are unlikely to be responsible for suppression of damping-off in the soil containing furanose or pyranose. The in vitro assays using PA (Cleveland and McCormick 1987) and CMC (Kasana et al. 2008) media showed that extracellular activities of both PG and endo$\beta$-1,4-glucanase produced by the pathogen were not affected when any of the monosaccharides, including galactose and glucose, were added to the respective detection media or to WA medium. The effects of sugar alcohols on the enzyme productions also were comparable with those of monosaccharides. Apparently, the pathogen produces both enzymes as long as their respective substrates are available. These results suggest that the enzymatic activities do not relate to disease incidence, because only monosaccharides but not sugar alcohols suppressed pathogenic as well as saprotrophic activities of the pathogen. However, such observations on enzymatic activities by in vitro assays may not precisely represent the roles of enzymes in the process of disease development (Isaac 1991). In addition, because the individual enzymes play only partial roles in the entire functions of pectinases and cellulases, respectively, our study does not completely exclude enzymatic degradation of the structural polysaccharides from the possible factors involved in suppression of damping-off in carbonized soils.
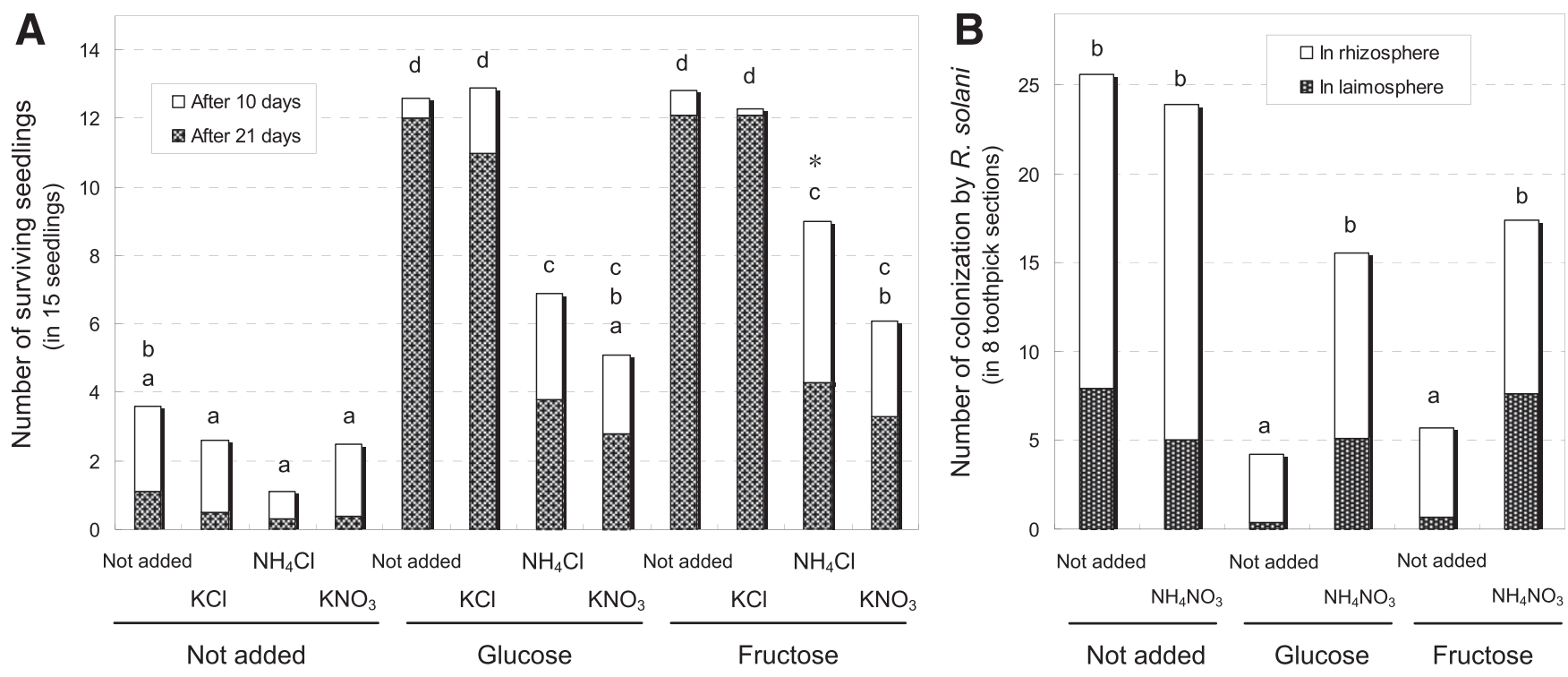

\section{Monosaccharides or inorganic compounds added to the soil}

Fig. 2. Effects of glucose or fructose added with inorganic nitrogenous compounds to the infested soil on $\mathbf{A}$, damping-off of sugar beet and $\mathbf{B}$, saprotrophic activity of Rhizoctonia solani. Glucose or fructose was added to the $R$. solani-infested pasteurized soil at the rate of $0.5 \%$ (wt/wt) with or without each inorganic chemical at a C/N ratio of $20: 1$ before adjusting soil moisture to $-10 \mathrm{kPa}$. A, Values are means of eight replicates, 15 seeds/replicate. All effects and their interactions were significant at $P<0.001$, except for the main-repeated measure interaction. According to the Student-Newman Keuls test, means for 21 days after sowing were not significantly different $(P=0.05)$ when indicated by the same letters. Means indicated by asterisks are significantly $(P=0.05)$ less than the corresponding counterpart values assessed earlier according to pairwise Tukey's test. Results of mean separation after 10 days are not shown. B, Values transformed by the multiple infection transformation are means of five replicates, eight sections per replicate. All three effects were significant at $P=0.003$ or less but any interactions with repeated measure were not significant according to analysis of variance. Average values of two repeated-measure means are not significantly different $(P=0.05)$ according to the Student-Newman Keuls test when indicated by the same letters. 

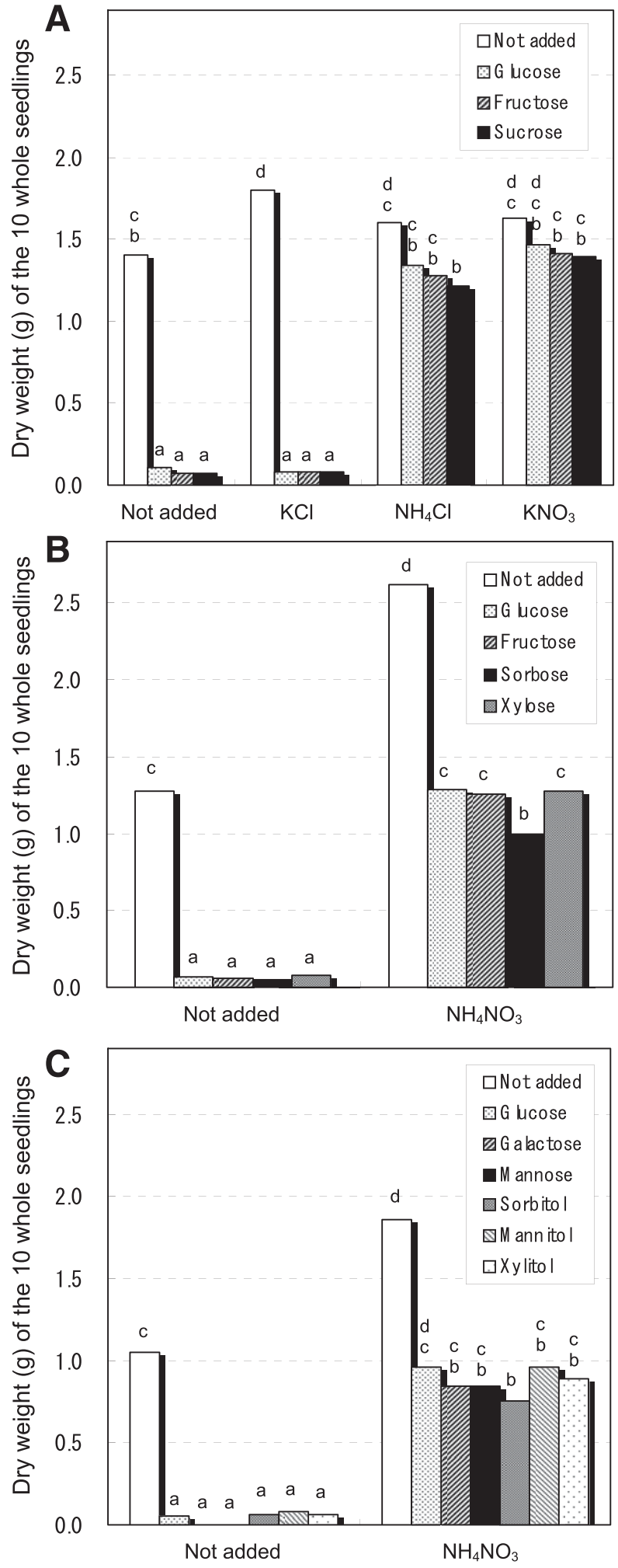

Fig. 3. Effects of inorganic nitrogenous compounds applied with simple sugars or sugar alcohols into the pasteurized soil on growth of sugar beet seedlings. Carbohydrates were added to the soil at molar concentrations equivalent to $0.5 \%$ (wt/wt) with glucose, and inorganic chemicals were applied in amounts to bring the $\mathrm{C} / \mathrm{N}$ ratio to 20:1. Seedlings were grown in $\mathbf{A}$, a glasshouse with day and night temperature set to 22 and $27^{\circ} \mathrm{C}$, respectively, for 42 days or $\mathbf{B}$ and $\mathbf{C}$, a regular glasshouse partially exposed to ambient weather conditions through insect-proof mesh for 43 days. Values are means of four replicates, each with 10 seedlings. Values for the samples with less than 10 growing seedlings were substituted with the average weight per seedling multiplied by 10 . Both effects and their interaction were significant at $P=0.002$ or less in all trials, except for the interaction being not significant in the third trial. Means indicated by the same letters are not significantly different $(P=0.05)$ in each trial according to multiple comparisons by Tukey's procedure.
Another key in determining the efficacy of disease suppression is the differential effect of carbohydrates on saprotrophic activities of the pathogen between sugar beet SMS versus LMS. Although none of the carbohydrates except sorbose inhibited pericarp colonization by the pathogen, saprotrophic colonization in LMS as well as RZS was suppressed efficiently for 7 days in the soil containing glucose, fructose, or xylose. In contrast, the suppressive effects induced in LMS amended with galactose and dried peanut residue vanished before 7 days after sowing. In general, the amounts of exudates in SMS are much greater than the amounts exuded in LMS or RZS (Bruehl 1987). The semiquantitative assay in this study indicated that one seed of sugar beet released approximately $7 \mu \mathrm{g}$ of inorganic nitrogen $\left(\mathrm{NH}_{4}^{+}\right.$and $\left.\mathrm{NO}_{3}^{-}\right)$while exuding no more than twice as much glucose containing six atoms of carbon. It was also shown that the accumulation of exudates in cotton SMS due to reduced microbial activities at low soil temperatures increased the incidence of preemergence damping-off by $R$. solani (Hayman 1969). These may suggest that the failure of most saccharides to suppress pericarp colonization by the pathogen is attributed to lower $\mathrm{C} / \mathrm{N}$ ratios in sugar beet SMS, with ample exudates containing mineral nitrogen as well as amino acids and other nitrogenous substances, in contrast to higher $\mathrm{C} / \mathrm{N}$ ratios in the experimental LMS, with wooden toothpicks releasing virtually no exudates in carbonized soils.

Hence, the results of soil fertilization trials reveal that microbial competition for nitrogen enhanced by an elevated $\mathrm{C} / \mathrm{N}$ ratio in sugar beet LMS is likely responsible for suppression of damping-off in the soils with specific monosaccharides. Because soil mineral nitrogen is immobilized by active soil microbes at a soil $\mathrm{C} / \mathrm{N}$ ratio of $20: 1$ or greater (Brady and Weil 2010; Davet 2004), fertilization of carbonized soils with inorganic nitrogen at $\mathrm{C} / \mathrm{N}$ ratio of 20:1 negated suppression of damping-off as well as saprotrophic colonization by the pathogen in LMS. However, it is not known whether $R$. solani, a common basidiomycetous soil inhabitant, requires lower $\mathrm{C} / \mathrm{N}$ ratios for its optimum growth than other soil microbes. It is also noteworthy that sorbose differed significantly from other monosaccharides in its inhibitory effects on the pathogen in SMS versus LMS, resembling peanut residue in their effects. That is, although both organic agents were effective in preventing pericarp colonization, they were mostly less effective than glucose or fructose in suppressing damping-off as well as saprotrophic colonization in LMS when added to the infested soil.

Kasuya et al. (2006) revealed that microbial interactions responsible for suppression of Rhizoctonia damping-off of sugar beet in the soil amended with dried peanut residue occurred essentially in its LMS rather than SMS. The prime antagonists were a specific group of indigenous soil bacteria proliferating in LMS with the residue because soil treatment with antibacterial antibiotics diminished disease suppression. This may relate to the effects of sorbose on disease suppression. It was reported that L-sorbose was fungistatic on $R$. solani by inhibiting hyphal extension, causing profuse hyphal branching, and protected cotton seed against damping-off when applied to the seed (Howell 1978). In this study, however, mycelial growth of the pathogen was not inhibited in a solution containing $2.0 \%(111 \mathrm{mM})$ L-sorbose. The results suggest that disease suppression by this ketose also depended on specific antagonistic bacteria proliferating in LMS because the antibiotics added to the soil containing sorbose nearly nullified disease suppression but did not assist saprotrophic activity of the pathogen in SMS. Nonetheless, the effects induced by such organic agents acting in SMS were less consistent overall in suppressing damping-off than those by other monosaccharides protecting LMS. Disease suppression induced by dried crop residues is also subject to other factors, including the kind of crop or cultivar (Kasuya et al. 2006), soil temperature (Matsui et al. 2013), and soil pH (Watanabe et al. 2011). In all, common saccharides such as glucose and sucrose are more dependable and realistic organic materials for use in disease management, because they are available universally in the market with ample supplies and lower costs.

An obvious paradox in our approach is that soil amendment with specific saccharides suppresses both the disease and seedling growth. However, the results did not indicate that seedling growth was inhibited unconditionally in carbonized soils. Fertilization with 
$\mathrm{NH}_{4} \mathrm{Cl}$ or $\mathrm{KNO}_{3}$ at a $\mathrm{C} / \mathrm{N}$ ratio of 20:1 restored the seedling growth in all cases, comparable with seedlings in soil with no added carbon and nitrogen. Notably, growth recovery was slightly greater with $\mathrm{KNO}_{3}$ than $\mathrm{NH}_{4} \mathrm{Cl}$ at the same molarity, which may reflect growth enhancement by $\mathrm{K}^{+}$because seedling growth was significantly promoted in the soil with $\mathrm{KCl}$. It may also suggest that the difference in soil microbial communities formed in the soil fertilized with ammonium versus nitrate.

Poor seedling growth in the soils with other carbohydrates, including sugar alcohols, also was restored when fertilized with $\mathrm{NH}_{4} \mathrm{NO}_{3}$, exhibiting the universal effect of $\mathrm{C} / \mathrm{N}$ ratio on plant growth. Even growth of the seedlings survived in the soil with mannose as well as galactose resuscitated when fertilized with inorganic nitrogen, suggesting that the inhibitory effect of mannose (Pego et al. 1999) and galactose on sugar beet seedlings may be nitrogen dependent. Although soil fertilization with $\mathrm{NH}_{4} \mathrm{Cl}$ did not reinstate repressed seedling growth to its normal rate, the delay in seedling growth in the fertilized soil containing glucose, fructose, or sucrose was no more than about a week. Such delays in seedling growth may be offset by advancing the time of sowing, which also might help reduce the incidence of damping-off of sugar beet because of lower soil temperature at earlier sowing dates (Matsui et al. 2013).

Zonal application of glucose to the surface soil layer was effective in reducing disease incidence while supplying inorganic nitrogen to the seedlings, especially when the $\mathrm{C} / \mathrm{N}$ ratio in the surface-soil zone was elevated to $50: 1$ or above. This indicates that, whereas sugar beet
LMS was protected successfully from the pathogen, the seedlings obtained inorganic nitrogen with their roots growing down below SMS, especially when the lines are resistant to Rhizoctonia root or crown rot (Gaskill 1967; Hecker and Ruppel 1975, 1988; Panella et al. 1995). The results also imply that damping-off may be suppressed effectively just by dressing sugar granules onto the surface of sufficiently fertilized soil, as long as the soil holds enough soil water for the sugar to dissolve and diffuse in LMS during seedling emergence. Obviously, much less sugar is needed to boost the soil $\mathrm{C} / \mathrm{N}$ ratio only in the surface-soil zone or on seeding slits or strips than to apply it into the entire zone of cultivated soil. Such simple methods of disease management with universal effects might be ideal for controlling $R$. solani with wide host ranges and greater pathogenic activities near or above the soil surface (Bruehl 1987).

Other industrial carbohydrates expected to be effective for this purpose include corn syrup and molasses from sugar beet or sugarcane (Saccharum officinarum L.), which are ready-to-use in solutions and may be obtained at lower cost than pure glucose or fructose. However, molasses may contain inorganic as well as organic nitrogen because it is extracted from plant tissues. In order to establish cost-effective methods of disease management and encourage recycling of natural resources, more studies are needed to compare efficacies of molasses and other natural carbohydrates (e.g., sugar phosphates, uronic acids, oligosaccharides, and glycosaminoglycan) on suppression of damping-off diseases.

Table 5. Effects of glucose added to the whole soil versus surface-soil zone on Rhizoctonia damping-off of sugar beet and seedling growth in the pasteurized soil fertilized with $\mathrm{NH}_{4} \mathrm{NO}_{3}$

\begin{tabular}{|c|c|c|c|c|c|c|}
\hline \multirow[b]{3}{*}{ Layer $(\mathrm{C} / \mathrm{N} \text { ratio })^{\mathrm{z}}$} & \multicolumn{4}{|c|}{$\begin{array}{l}\text { Seedlings survival (in } 15 \text { seeds) in the pasteurized soil infested with } \\
\text { Rhizoctonia solani }(n=6)^{\mathrm{v}}\end{array}$} & \multicolumn{2}{|c|}{$\begin{array}{l}\text { Dry weight }(\mathrm{mg}) \text { of } 10 \text { seedlings } \\
\text { grown in the pasteurized soil } \\
\text { without } R \text {. solani }(n=4)^{\mathrm{w}}\end{array}$} \\
\hline & \multicolumn{2}{|c|}{ First trial $^{x}$} & \multicolumn{2}{|c|}{ Second trialy } & \multirow[b]{2}{*}{ No nitrogen } & \multirow[b]{2}{*}{ With $\mathrm{NH}_{4} \mathrm{NO}_{3}$} \\
\hline & After 10 days & After 23 days & After 10 days & After 23 days & & \\
\hline \multicolumn{7}{|l|}{ No nitrogen added } \\
\hline Nontreated & $12.0 \mathrm{a}$ & $3.2 a$ & $7.7 \mathrm{a}$ & $6.3 \mathrm{ab}$ & $963.3 \mathrm{c}$ & $\ldots$ \\
\hline Whole soil (20:0) & $13.0 \mathrm{a}$ & $13.3 \mathrm{de}$ & $13.0 \mathrm{c}$ & $13.0 \mathrm{c}$ & $70.3 \mathrm{a}$ & $\ldots$ \\
\hline Surface zone (20:0) & $13.2 \mathrm{a}$ & $11.2 \mathrm{~d}$ & $13.2 \mathrm{c}$ & $11.0 \mathrm{c}$ & $606.8 \mathrm{bc}$ & $\ldots$ \\
\hline Surface zone (50:0) & $13.2 \mathrm{a}$ & $13.2 \mathrm{de}$ & $13.0 \mathrm{c}$ & $13.2 \mathrm{c}$ & $575.5 \mathrm{~b}$ & $\ldots$ \\
\hline Surface zone (125:0) & $13.0 \mathrm{a}$ & $12.8 \mathrm{de}$ & $13.7 \mathrm{c}$ & $13.7 \mathrm{c}$ & $702.5 \mathrm{bc}$ & $\ldots$ \\
\hline Not infested & $12.7 \mathrm{a}$ & $12.8 \mathrm{de}$ & $13.2 \mathrm{c}$ & $13.2 \mathrm{c}$ & $\ldots$ & $\ldots$ \\
\hline \multicolumn{7}{|l|}{ With added $\mathrm{NH}_{4} \mathrm{NO}_{3}$} \\
\hline Nontreated & $12.2 \mathrm{a}$ & $3.8 a$ & $7.5 \mathrm{a}$ & $5.5 \mathrm{a}$ & $\ldots$ & $2,413.0 \mathrm{e}$ \\
\hline Whole soil (20:1) & $13.8 \mathrm{a}$ & $7.2 b$ & $6.2 \mathrm{a}$ & $5.0 \mathrm{a}$ & $\ldots$ & $646.3 \mathrm{bc}$ \\
\hline Surface zone (20:1) & $13.2 \mathrm{a}$ & $5.3 a$ & $7.5 \mathrm{a}$ & $5.5 \mathrm{a}$ & $\ldots$ & $1,773.0 \mathrm{~d}$ \\
\hline Surface zone (50:1) & $12.8 \mathrm{a}$ & $9.3 c$ & $10.5 \mathrm{~b}$ & $8.0 \mathrm{~b}$ & $\ldots$ & $2,229.0 \mathrm{e}$ \\
\hline Surface zone (125:1) & $12.7 \mathrm{a}$ & $11.2 \mathrm{~d}$ & $12.8 \mathrm{c}$ & $12.5 \mathrm{c}$ & $\ldots$ & $1,732.8 \mathrm{~d}$ \\
\hline Not infested & $13.2 \mathrm{a}$ & $13.7 \mathrm{e}$ & $13.5 \mathrm{c}$ & $13.5 \mathrm{c}$ & $\ldots$ & $\ldots$ \\
\hline \multicolumn{7}{|l|}{ Probability } \\
\hline Main effect (ME) & $\ldots$ & & $\ldots$ & & $<0.001$ & \\
\hline Effect of glucose (G) & $<0.001$ & & $<0.001$ & & $\ldots$ & \\
\hline Effect of nitrogen $(\mathrm{N})$ & $<0.001$ & & $<0.001$ & & $<0.001$ & \\
\hline $\mathrm{ME} \times \mathrm{N}$ interaction & $\ldots$ & & $\ldots$ & & $<0.001$ & \\
\hline $\mathrm{G} \times \mathrm{N}$ interaction & $<0.001$ & & $<0.001$ & & $\ldots$ & \\
\hline Repeated measure (R) & $<0.001$ & & $<0.001$ & & $\ldots$ & \\
\hline $\mathrm{G} \times \mathrm{R}$ interaction & $<0.001$ & & $<0.001$ & & $\ldots$ & \\
\hline $\mathrm{N} \times \mathrm{R}$ interaction & $<0.001$ & & $<0.001$ & & $\cdots$ & \\
\hline Three-way interaction & $<0.001$ & & 0.031 & & $\ldots$ & \\
\hline
\end{tabular}

${ }^{v}$ Values are means of six replicates (90 seeds in total). Means indicated by the same letters are not significantly different $(P=0.05)$ within each assessment day according to the Student-Newman Keuls test. Means indicated by bold italic letters are significantly smaller $(P=0.05)$ than their corresponding counterpart values assessed earlier according to pairwise Tukey's least significant difference test.

${ }^{w}$ Seedlings were grown in the semiheated glasshouse for 42 days from March through April, with the mean, minimum, and maximum temperatures at 17.8, 9.9, and $41.4^{\circ} \mathrm{C}$, respectively, and dry weights of 10 seedlings were determined with four replicates ( 40 seedlings in total). Means indicated by the same letters are not significantly different $(P=0.05)$ according to Tukey's test.

x Seedlings were grown in a regular glasshouse from February through March, with the mean, minimum, and maximum temperatures at $17.5,9.1$, and $35.0^{\circ} \mathrm{C}$, respectively.

y Seedlings were grown in a regular glasshouse from April through May, with the mean, minimum, and maximum temperatures at $22.6,11.1$, and $38.2^{\circ} \mathrm{C}$, respectively.

${ }^{z}$ Soil treatment and soil layer with added glucose $\left(\mathrm{C} / \mathrm{N}\right.$ ratio). Glucose was added to the $R$. solani-infested pasteurized soil amended with $\mathrm{NH}_{4} \mathrm{NO}_{3}$ at the amounts to adjust to the respective $\mathrm{C} / \mathrm{N}$ ratios in the whole soil or surface $1.5-\mathrm{cm}$ soil layer. 


\section{Acknowledgments}

We thank J. Ole Becker, Department of Nematology, University of California at Riverside, for critical reading of the manuscript; the National Institute of Agrobiological Sciences for providing the strain of $R$. solani; and Hokkaido Sugar, Co., Ltd. for supplying sugar beet seed.

\section{Literature Cited}

Andrić, P., Meyer, A. S., Jensen, P. A., and Dam-Johansen, K. 2010. Reactor design for minimizing product inhibition during enzymatic lignocellulose hydrolysis: I. Significance and mechanism of cellobiose and glucose inhibition on cellulolytic enzymes. Biotechnol. Adv. 28:308-324.

Bolton, M. D., Panella, L., Campbell, L., and Khan, M. F. R. 2010. Temperature, moisture, and fungicide effects in managing Rhizoctonia root and crown rot of sugar beet. Phytopathology 100:689-697.

Borneman, J., and Becker, J. O. 2007. Identifying microorganisms involved in specific pathogen suppression in soil. Annu. Rev. Phytopathol. 45:153-172.

Brady, N. C., and Weil, R. R. 2010. Elements of the Nature and Properties of Soil, 3rd ed. Prentice Hall, Upper Saddle River, NJ.

Bruehl, G. W. 1987. Soilborne Plant Pathogens. Macmillan Publishing Company, NY.

Cleveland, T. E., and McCormick, S. P. 1987. Identification of pectinases produced in cotton bolls infected with Aspergillus flavus. Phytopathology 77:1498-1503.

Cook, R. J. 2000. Advances in plant health management in the twentieth century. Annu. Rev. Phytopathol. 38:95-116.

Cook, R. J. 2006. Toward cropping systems that enhance productivity and sustainability. Proc. Natl. Acad. Sci. USA 103:18389-18394.

Davet, P. 2004. Microbial Ecology of the Soil and Plant Growth. Science Publishers, Inc., Enfield, NH.

Djébali, N., Elkahoui, S., Taamalli, W., Hesseni, K., Tarhouni, B., and Mrabet, M. 2014. Tunisian Rhizoctonia solani AG3 strains affect potato shoot macronutrient, infect faba bean plants, and show in vitro resistance to azoxystrobin. Aust. Plant Pathol. 43:347-358.

Führer Ithurrart, M. E., Büttner, G., and Peterson, J. 2004. Rhizoctonia root rot in sugar beet (Beta vulgaris ssp. altissima)-epidemiological aspects in relation to maize (Zea mays) as a host plant. J. Plant Dis. Prot. 111:302-312.

Fukui, R. 2003. Suppression of soilborne plant pathogens through community evolution of soil microorganisms. Microbes Environ. 18:1-9.

Fukui, R., Campbell, G. S., and Cook, R. J. 1994a. Factors influencing the incidence of embryo infection by Pythium spp. during germination of wheat seeds in soil. Phytopathology 84:695-702.

Fukui, R., Schroth, M. N., Hendson, M., Hancock, J. G., and Firestone, M. K. 1994b. Growth patterns and metabolic activity of pseudomonads in sugar beet spermospheres: Relationship to pericarp colonization by Pythium ultimum. Phytopathology 84:1331-1338.

Garbeva, P., van Veen, J. A., and van Elsas, J. D. 2004. Microbial diversity in soil: Selection of microbial populations by plant and soil type and implications for disease suppressiveness. Annu. Rev. Phytopathol. 42:243-270.

Gaskill, J. O. 1967. Breeding for Rhizoctonia resistance in sugarbeet. J. Am. Soc. Sugar Beet Technol. 15:105-119.

Gregory, P. H. 1948. The multiple infection transformation. Ann. Appl. Biol. 35:412-417.

Hayman, D. S. 1969. The influence of temperature on the exudation of nutrients from cotton seeds and on preemergence damping-off by Rhizoctonia solani. Can. J. Bot. 47:1663-1669.

Hecker, R. J., and Ruppel, E. G. 1975. Inheritance of resistance to Rhizoctonia root rot in sugarbeet. Crop Sci. 15:487-490.

Hecker, R. J., and Ruppel, E. G. 1988. Registration of Rhizoctonia root rot resistant sugarbeet germplasm FC709. Crop Sci. 28:1039.
Hillel, D. 2004. Introduction to Environmental Soil Physics. Elsevier/Academic Press, San Diego, CA.

Hoitink, H. A. J., and Boehm, M. J. 1999. Biocontrol within the context of soil microbial communities: A substrate-dependent phenomenon. Annu. Rev. Phytopathol. 37:427-446.

Howell, C. R. 1978. Seed treatment with L-sorbose to control damping-off of cotton seedlings by Rhizoctonia solani. Phytopathology 68:1096-1098.

Isaac, S. 1991. Fungal-Plant Interactions. Chapman \& Hall, New York.

Kasana, R. C., Salwan, R., Dhar, H., Dutt, S., and Gulati, A. 2008. A rapid and easy method for the detection of microbial cellulases on agar plates using Gram's iodine. Curr. Microbiol. 57:503-507.

Kasuya, M., Olivier, A. R., Ota, Y., Tojo, M., Honjo, H., and Fukui, R. 2006. Induction of soil suppressiveness against Rhizoctonia solani by incorporation of dried plant residues into soil. Phytopathology 96:1372-1379.

Kirk, W. W., Wharton, P. S., Schafer, R. L., Tumbalam, P., Poindexter, S., Guza, C., Fogg, R., Schlatter, T., Stewart, J., Hubbell, L., and Ruppal, D. 2008 Optimizing fungicide timing for the control of Rhizoctonia crown and root rot of sugar beet using soil temperature and plant growth stages. Plant Dis. 92:1091-1098.

Luttrell, E. S. 1958. The perfect stage of Helminthosporium turcicum. Phytopathology 48:281-287.

Matsui, M., Honjo, H., Becker, J. O., and Fukui, R. 2013. Temperature-dependent effects of soil amendment with crop residues on suppression of Rhizoctonia damping-off of sugar beet. Plant Soil 366:467-477.

Mazzola, M. 2004. Assessment and management of soil microbial community structure for disease suppression. Annu. Rev. Phytopathol. 42:35-59.

Morita, Y., and Tojo, M. 2007. Modifications of PARP medium using fluazinam, miconazole, and nystatin for detection of Pythium spp. in soil. Plant Dis. 91: 1591-1599.

Motisi, N., Montfort, F., Faloya, V., Lucas, P., and Doré, T. 2009. Growing Brassica juncea as a cover crop, then incorporating its residues provide complementary control of Rhizoctonia root rot of sugar beet. Field Crops Res. 113:238-245.

Nagendran, S., Hammerschmidt, R., and McGrath, J. M. 2009. Identification of sugar beet germplasm EL51 as a source of resistance to post-emergence Rhizoctonia damping-off. Eur. J. Plant Pathol. 123:461-471.

Panella, L. W., Ruppel, E. G., and Hecker, R. J. 1995. Registration of four multigerm sugarbeet germplasms resistant to Rhizoctonia root rot: FC716, FC717, FC718, and FC719. Crop Sci. 35:291-292.

Paulitz, T. C., and Schroeder, K. L. 2005. A new method for the quantification of Rhizoctonia solani and R. oryzae from soil. Plant Dis. 89:767-772.

Pego, J. V., Weisbeek, P. J., and Smeekens, S. C. M. 1999. Mannose inhibits Arabidopsis thaliana germination via a hexokinase-mediated step. Plant Physiol. 119:1017-1024.

Rosa, E. A. S., and Rodrigues, P. M. F. 1999. Toward a more sustainable agriculture system: The effect of glucosinolates on the control of soil-borne diseases. J. Hortic. Sci. Biotechnol. 74:667-674.

Watanabe, K., Matsui, M., Honjo, H., Becker, J. O., and Fukui, R. 2011. Effects of soil $\mathrm{pH}$ on Rhizoctonia damping-off of sugar beet and disease suppression induced by soil amendment with crop residues. Plant Soil 347:255-268.

Webster, C. C., and Wilson, P. N. 1980. Agriculture in the Tropics. Longman, New York.

Weinhold, A. R., and Bowman, T. 1974. Repression of virulence in Rhizoctonia solani by glucose and 3-O-methyl glucose. Phytopathology 64:985-990.

Weller, D. M., Raaijmakers, J. M., Gardener, B. B., and Thomashow, L. S. 2002. Microbial populations responsible for specific soil suppressiveness to plant pathogens. Annu. Rev. Phytopathol. 40:309-348. 